\title{
Poesía
}

\section{Poesía Covid-19}

\author{
Ciro Maguiña-Vargas ${ }^{1}$
}

\section{Coronavirus}

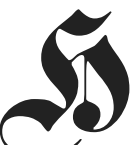
ace unos meses Surgiste de lo invisible Te llamaron coronavirus

Porque tú si tienes corona

Para detener la tierra un instante ...

Para que la humanidad alguna vez

Reflexione, recapacite, piense y

Valore todo lo que tiene a su alrededor.

Valore un tierno abrazo

Valore un beso amoroso

Valore un paseo en el parque

Valore saborear un café vespertino

Valore la libertad

Valore un viaje de paseo en un bus

Valore la sencillez de la vida.

Has logrado algo impensable

Parar la tierra un instante

Ninguna potencia lo hizo

Ningún poder económico la detuvo

Ninguna religión la contuvo

Ningún político lo soñó.

Extraño coronavirus

Hoy causas muerte y dolor

Miedo y pavor

El mundo está en crisis

No hay arma que te detenga

Pero al frente de los males que causas

Están siempre los ángeles de blanco

Médicos y trabajadores de la salud

Profesor principal. Facultad de Medicina, Universidad

Peruana Cayetano Heredia, Lima, Perú.
Buscando siempre calmar y aliviar el daño.

Extraño y minúsculo virus

Hoy los hombres te tienen miedo

Más no la naturaleza

Hoy los pájaros vuelan felices

Hoy los delfines surcan libres por los mares

Hoy las flores desprenden sus mejores

fragancias

Hoy la tierra se siente libre y feliz

Hoy la tierra descansa alguna vez.

Una vez más

Ante está impensable crisis mundial

La humanidad resistirá

Luchará

Se unirá y lo derrotará

Sacando nuevas y valiosas lecciones

12 de abril, 2020

\section{CuÁnto Dolor}

Cuánto dolor

Cuánta impotencia siento hoy

Cuánto sufrimiento hay por doquier

Alguien nos llama y pide

¡Sálvenos!

Otro nos dice

No hay camas en UCI

No hay ventiladores

Mi hermano se muere, doctor.

Más allá alguien pregunta

¿Estamos en meseta?

Otro indaga ¿funcionó el martillazo?

Pero los enfermos siguen creciendo y

Los muertos se quedan en sus casas 
O llegan a su destino final en las emergencias

Cuánto dolor siento hoy

Cuánto llanto

Cuánta rabia

Cuánta impotencia

Esta pandemia del coronavirus.

Es inédita, dolorosa

Cruel

Causa miedo

Causa pavor

Alguien interroga ¿nos falta oxígeno?

Muchos dicen nos falta salud

Otros afirman, nos falta todo
No sabemos cuándo termine

No basta estar en cuarentena

Cuando azota el hambre

Cuando falta el aire

Cuando hay tanta desgracia...

Pero veo también

Mucha entrega

Mucha solidaridad

Mucho valor

Mucha resistencia

Mucha valentía

Mucho amor...

Cuánto dolor siento hoy...

6 de junio, 2020

FECHA DE RECEPCIÓN: 07-06-2020

FECHA DE ACEPTACIÓN: 10-07-2020 